\title{
Evaluation of Four Poplar Clones in a Short Rotation Forestry in Central Italy
}

\author{
Euro Pannacci*, Simone Bartolini, Gino Covarelli \\ Dipartimento di Scienze Agrarie e Ambientali, Università di Perugia \\ Borgo XX Giugno 74, 06121 Perugia, Italy
}

Received: 14 September 2009. Accepted: 28 October 2009.

\begin{abstract}
Two field experiments were carried out in 2006 and 2007 in central Italy $\left(42^{\circ} 57^{\prime} \mathrm{N}, 12^{\circ} 22^{\prime} \mathrm{E}, 165 \mathrm{~m}\right.$ a.s.l.) in order to investigate the influence of site, planting densities/spacings and cutting cycles on the biomass production of four poplar clones [(Populus - generosa $)$ - Populus nigra "Monviso" and "AF6", Populus - canadensis "AF2", Populus deltoides - Populus - canadensis "SIRIO"] selected for SRF. Hardwood cuttings of each clone were planted at two different densities and planting designs: a) low density $=5500$ cuttings ha ${ }^{-1}$ were placed in a single-row design; $b$ ) high density $=11000$ cuttings ha ${ }^{-1}$ were placed in a coupled-row design, and were tested with two cutting cycles: one-year cycle and two-year cycle. The experimental design was a split-plot with three replicates. The initial survival of clones was recorded after the establishment period. The number of shoots per plant (stool) was determined after the first growing season. Plant height (height of the main stem), main stem diameter at a height of $1 \mathrm{~m}$ and of $1.3 \mathrm{~m}$ above the ground and biomass production were measured from each plot, every year at harvesting time at the end of the growing season. Plant samples were also taken in order to assess humidity content, lower and higher heating values (LHV and HHV) and ash content of poplar biomass. All poplar clones showed a very high stool survival with values ranged from $95 \%$ to $99 \%$. Monviso and AF2 can be advisable thanks to the higher biomass production than AF6 and Sirio. Considering planting density, low density (5500 plants ha $\left.{ }^{-1}\right)$ seems to be more advisable than high density (11000 plants ha $\left.{ }^{-1}\right)$ in order to obtain good biomass production with low planting cost. Considering cutting cycles, two-year cutting cycle allows higher biomass production (5.8 odt ha ${ }^{-1}$ year $^{-1}$ ) than oneyear cutting cycle $\left(4.7\right.$ odt ha $^{-1}$ year $\left.^{-1}\right)$, regardless of clones or density. Concerning main stem height and diameter some interesting equations were found in order to explain the relationship between them or with biomass production. In particular, a functional relationship between dry biomass production and stool diameter, appropriate for this climatic area and environmental conditions, was found. Analysis concerning wood energy content showed a good quality of poplar biomass thanks to high HHV and LHV values (an average of $19.7 \mathrm{MJ} \mathrm{Kg}^{-1}$ and $19.4 \mathrm{MJ} \mathrm{Kg}^{-1}$ ), low ash content (an average 3.6\%) and low biomass humidity at harvest (an average 54\%).
\end{abstract}

Key-words: biomass production, clone evaluation, cutting cycles, poplar, short rotation forestry, spacing.

\section{Introduction}

In short rotation forestry (SRF) fast growing hardwoods of good coppicing ability are used in carefully tended plantations to produce woody biomass (Pellis et al., 2004). SRF has the potential to become an important source of renewable energy in Europe because of high biomass yields, good combustion quality as solid fuel and ecological advantages (Kauter et al., 2003). In Italy there is an increasing interest in the use of SRF crops as renewable energy sources, taking advantage of their low input requirement and of their alternative use for the land taken out of agricultural production (Facciotto et al., 2006). In particular, during the last few year, poplar (Populus spp.), already cultivated in Northern Italy at low planting density to produce pulp-wood and wood-based panels, has been found to be the most productive and reliable species for SRF (Di Muzio Pasta et al., 
2007). The characteristics that have contributed to the success of poplar species and their hybrids include: ease of propagation, quick establishment, fast growth, vigorous sprouting after cutting and suitability for a variety of wood fibre products (Pontailler et al., 1999; Zalesny et al., 2007). However, because of high cost of biomass production and agricultural subsidies, energy from SRF is uncompetitive with fossil fuels without subsidies of its own (Facciotto et al., 2003). Consequently, in order to promote the use of biomass from SRF as an energy source, it is essential to minimize this need for subsidy. This can, among others, be attained by increasing the biomass yield, decreasing costs for its production, using and optimizing fuel quality (Kauter et al., 2003). It is particularly important to establish clones, planting densities/spacings and cutting cycles that ensure the best utilization of the site (Armstrong et al., 1999).

The aim of this work was to investigate, in central Italy, the influence of site, planting densities/spacings and cutting cycles on the biomass production of four poplar clones selected for SRF. It was also found a functional relationship between dry biomass production and stool diameter, appropriate for this climatic area and environmental conditions.

\section{Materials and methods}

Two field experiments were carried out in 2006 and 2007 in central Italy (Experimental Station of Papiano, $42^{\circ} 57^{\prime} \mathrm{N}, 12^{\circ} 22^{\prime} \mathrm{E}, 165 \mathrm{~m}$ a.s.l.) on a clay-loam soil (22\% sand, $35 \%$ clay and $43 \%$ silt, $1.5 \%$ organic matter). Four poplar clones, suited to IT conditions, were selected: (Populus $\times$ generosa $) \times$ Populus nigra "Monviso" and "AF6", Populus × canadensis "AF2", Populus deltoides $\times$ Populus $\times$ canadensis "SIRIO". Hardwood cuttings ( $0.25 \mathrm{~m}$ long) of each clone were planted at two different densities and planting designs: a) low density $=5500$ cuttings $\mathrm{ha}^{-1}$ were placed in a single-row design $(3.0 \mathrm{~m}$ inter-row distance $\times 0.6 \mathrm{~m}$ intra-row distance); b) high density $=11000$ cuttings ha ${ }^{-1}$ were placed in a coupled-row design (3.75 $\mathrm{m}$ inter-coupledrow distance $\times 0.75 \mathrm{~m}$ inter-row distance on each coupled-row $\times 0.48 \mathrm{~m}$ intra-row distance) and were tested with two cutting cycles: oneyear cycle (harvested every 1 year after planti- ng) and two-year cycle (harvested every 2 years after planting).

The experimental design was a split-plot with three replicates (blocks) and three main experimental treatments (factors): 1) two planting densities (main plot); 2) four clones (subplot); 3) two cutting cycles (sub-sub-plot). The size of the plot was the following: main plot of $294 \mathrm{~m}^{2}$ (10.5 m width); sub-plot of $73.5 \mathrm{~m}^{2}$ (10.5 $\mathrm{m}$ width); sub-sub-plot of $36.8 \mathrm{~m}^{2}(10.5 \mathrm{~m}$ width). Two border rows of trees were established on the perimeter of each plots to reduce potential border effects (Hansen, 1981; Zavitkovski, 1981).

The main agronomic practices are showed in Table 1. Crop was carried out in accordance with recommended management practices in Italy (Facciotto, 1998; Istituto Sperimentale per la Pioppicoltura, 2000). In particular, nitrogen fertilization was not applied and the plantation was only irrigated shortly after planting to promote a better establishment (see Tab. 1). Irrigations were not applied during the subsequent growing seasons.

The plots were kept weed free with cultivation during site preparation, application of preemergence herbicide (isoxaben $500 \mathrm{~g} \mathrm{ha}^{-1}$ ) just after planting and subsequently mechanical weed control treatments as needed.

\section{Measurements and statistical analysis}

The initial survival of clones was recorded after the establishment period. The number of shoots per plant (stool) was determined after the first growing season. Plant height (height of the main stem) $(H)$, main stem diameter at a height of 1 $\mathrm{m}\left(D_{1}\right)$ and of $1.3 \mathrm{~m}(D B H$, Diameter at breast height) above the ground and biomass per plant were measured from five plants per plot, every year at harvesting time, at the end of the growing season. The one-year cutting cycle plots for each clones were harvested at the end of November 2006 (plants aged one year both in root and shoot $=$ R1S1) and in the middle of De-

Table 1. Main agronomic practices in the field experiment.

\begin{tabular}{ll}
\hline Preceding crop & Sunflower \\
Fertilization $\left(\mathrm{kg} \mathrm{ha}^{-1}\right)$ & $100 \mathrm{P}_{2} \mathrm{O}_{5}+100 \mathrm{~K}_{2} \mathrm{O}$ \\
Planting date & 4 April 2006 \\
Irrigation $\left(\mathrm{m}^{3} \mathrm{ha}^{-1}\right)$ & 250 (May 2006); 300 (July 2006) \\
Harvesting date & 29 Nov. 2006; 13 Dec. 2007
\end{tabular}


cember 2007 (plants aged two years in root and one year in shoot $=\mathrm{R} 2 \mathrm{~S} 1$ ); the two-year cutting cycle plots were harvested in the middle of December 2007 (plants aged two years both in root and shoot = R2S2) (see Tab. 1). The plants from the two central single-row or coupled-row of each plot were cut, by chainsaw, $50 \mathrm{~mm}$ above the ground level, removed manually and weighed. A sample from each plot (about 10\% of total fresh biomass) was taken, collecting three levels of the plants (basal part, breastheight level and branches). The samples were then weighed green, oven dried at $105^{\circ} \mathrm{C}$ to a constant weight in order to assess humidity content, dry weight of biomass and then an equivalent yield [oven dry tonnes per hectare $\left(\right.$ odt ha $\left.{ }^{-1}\right)$ ] for each plot. These samples were also analysed to determine lower and higher heating values (LHV and HHV) and ash content of biomass, using, respectively, a calorimeter (AC-350 Leco) and a thermo-gravimetrical analyzer (TGA-701 Leco).

In 2007, also the thickness of the bark and the diameter of the main stem were determined at a height of $50 \mathrm{~mm}$ above the ground, on the cutting area of three plants per plot. The bark content was expressed as a percentage of bark surface on total cutting surface.

The data of $H$ and $D B H$ were subjected to a non-linear regression analyses by using the model proposed by Pettersson (1955):

$$
H=130+\frac{(a+b)^{-3}}{D B H}
$$

where $H$ and $D B H$ are the above mentioned parameters and $a$ and $b$ are parameters of the model. Furthermore, the data of $D_{1}$ and the dry weight of each plant $(D W)$ were subjected to a non-linear regression analyses by using the model proposed by Di Muzio Pasta et al., 2007:

$$
D W=k D_{1}^{a}
$$

with $k$ and $a$ as parameters of the model.

All data were subjected to analysis of variance (ANOVA) and treatment means were separated using Fisher's protected LSD at $\mathrm{P}=0.05$ level. Analysis of variance was performed with the EXCEL $^{\circledR}$ Add-in macro DSAASTAT (Onofri, 2006). All the non-linear models were directly fitted to the experimental data, by us- ing the software open-source R (Wirtschaftsuniversität, 2009). The goodness-of-fit was assessed by graphical analyses of residuals and Ftest for lack-of-fit (Bates and Watts, 1988).

\section{Meteorological data}

Meteorological data (daily maximum and minimum temperature and rainfall) were collected from a nearby station. Decadic averages were calculated and compared with poliennal averages (Fig. 1). Temperatures and rainfalls were not different between 2006 and 2007, except for the high rainfall in September 2006 (Fig. 1). However, annual rainfall did not differ among the two years, with $595 \mathrm{~mm}$ in 2006 and $551 \mathrm{~mm}$ in 2007.

\section{Results and discussion}

In 2006, the stool survival and the main stem diameter $\left(D_{1}\right)$ of the R1S1 poplar clones showed not significant differences among treatments with mean values ranged from $95 \%$ to $99 \%$ and from $23 \mathrm{~mm}$ to $27 \mathrm{~mm}$, respectively (Tab. 2). Considering main stem height $(H)$ and shoots per plant, significant differences were observed only among clones. In particular, AF2 showed the highest $H$ value $(3.46 \mathrm{~m})$, Monviso and AF6 the highest number of shoots per plant (1.9) (Tab. 2).

In 2007, AF2 and Monviso showed the highest $H$ values both in R2S1 and in R2S2 plants,

Table 2. Survival, diameter height and shoots per plant on R1S1 poplar clones.

\begin{tabular}{lcccc}
\hline $\begin{array}{l}\text { Experimental } \\
\text { treatment }\end{array}$ & $\begin{array}{c}\text { Stool } \\
\text { survival } \\
(\%)\end{array}$ & $\begin{array}{c}\text { Main stem } \\
\text { diameter } \\
\left(D_{1}\right)(\mathrm{mm})\end{array}$ & $\begin{array}{c}\text { Main stem } \\
\text { height } \\
(\mathrm{m})\end{array}$ & $\begin{array}{c}\text { Shoots } \\
\text { plant }^{-1} \\
(\mathrm{n} .)\end{array}$ \\
\hline MONVISO & 97 & 25 & $3.36 \mathrm{ab}$ & $1.9 \mathrm{a}$ \\
$\mathrm{AF} 2$ & 99 & 25 & $3.46 \mathrm{a}$ & $1.3 \mathrm{~b}$ \\
$\mathrm{AF6}$ & 98 & 25 & $3.26 \mathrm{~b}$ & $1.9 \mathrm{a}$ \\
SIRIO & 95 & 24 & $3.22 \mathrm{~b}$ & $1.5 \mathrm{ab}$ \\
\hline High density & 97 & 23 & 3.23 & 1.8 \\
Low density & 98 & 27 & 3.42 & 1.4 \\
\hline clones & n.s. & n.s. & $*$ & $* *$ \\
density & n.s. & n.s. & n.s. & n.s. \\
clones vs density & n.s. & n.s. & n.s. & n.s. \\
\hline
\end{tabular}

Means in vertical sequence not followed by the same letter are significantly different at $P=0.05$ according to LSD test. N.s., not significant; * $P=0.05 ; * * P=0.01$. R1S1: plants aged one year both in root and shoot. 

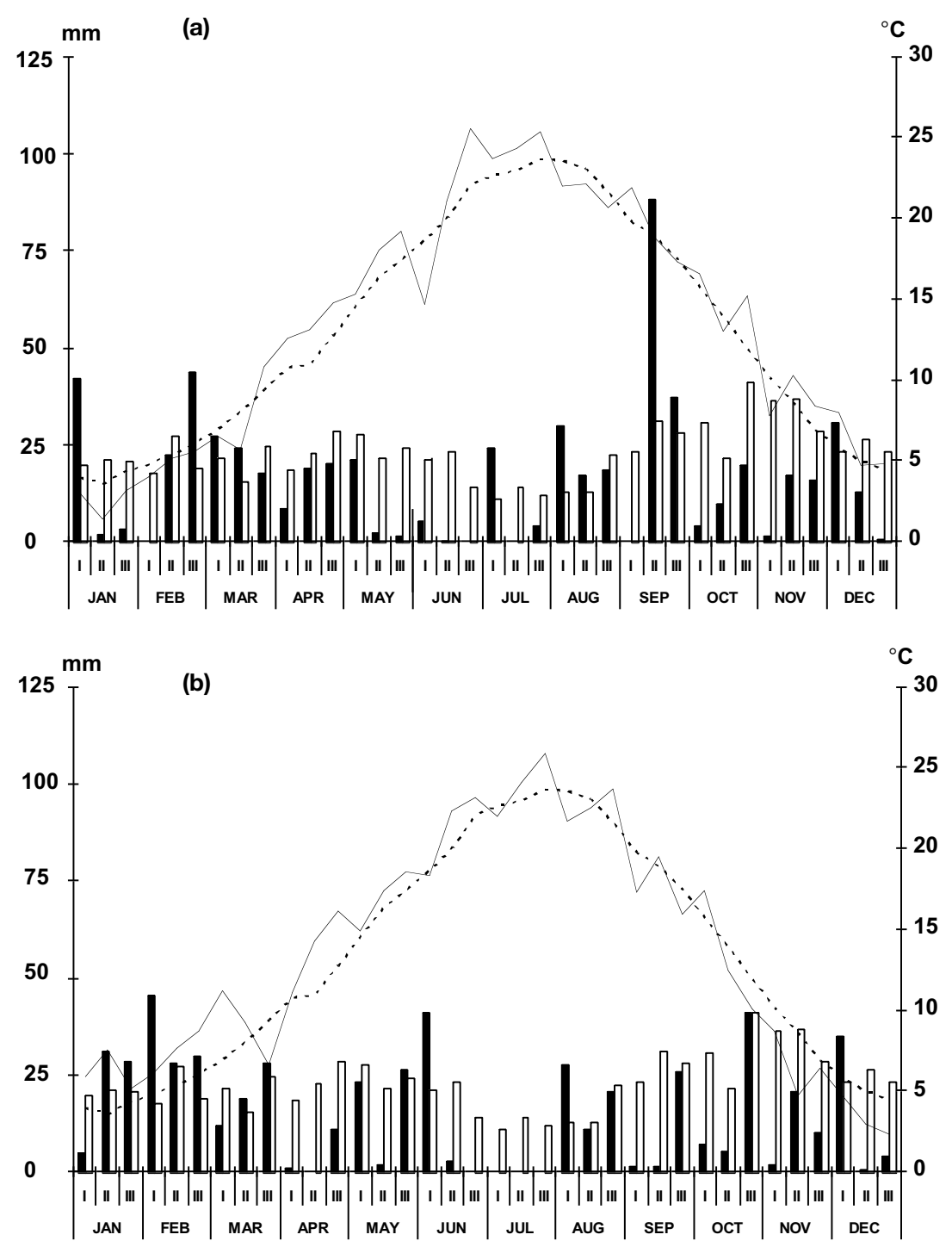

Figure 1. Average decade values of rainfall (mm; bold bar) and temperature $\left({ }^{\circ} \mathrm{C}\right.$; solid line) recorded during the experimental trial in 2006 (a) and 2007 (b), compared to pluriennial (1921-2005) averages (rainfall: mm, empty bar; temperature: ${ }^{\circ} \mathrm{C}$, sketched line).

confirming the results obtained in 2006; not significant differences were found among densities for main stem height (Tab. 3). Concerning $D_{1}$, significant differences were among clones, both in R2S1 and in R2S2 plants, and among densities only in R2S2 plants. In this last case clones with high planting density showed the lowest $D_{1}$ value (34 $\mathrm{mm}$ in average) due to the intra-specific competitiveness more prolonged in R2S2 plants (two-year cutting cycle) than in R2S1 (one-year cutting cycle) (Tab. 3).

The model 1 fitted the $H$ and $D B H$ data well (graphical analysis of residuals and F-test not reported) providing the following estimated parameters: $a=0.1161(\mathrm{P}=0.001) ; b=0.0965(\mathrm{P}=$ 0.001) (Fig. 2). Furthermore, non-linear regres- sion analysis performed on $D_{1}$ and $D W$ data, according to the model 2 , allowed to find a highly significant relationship which can be used for a non-destructive prediction of dry yield (Fig. $3)$. The relationship is a power function $\left(R^{2}=\right.$ $0.961, \mathrm{P}=0.01)$ and the relative estimated parameters are $k=0.0002$ and $a=2.445$ (Fig. 3).

Considering dry biomass production, the yield obtained, in 2006, from R1S1 plants (one year cutting cycle) showed significant differences between clones and planting densities (Tab. 4). In particular, among poplar clones, Monviso gave the highest yield (4.61 odt ha-1) while Sirio the lowest yield (3.71 odt $\left.\mathrm{ha}^{-1}\right)$. Among planting densities, the yield obtained from high planting density was significantly 
Table 3. Main effect of experimental treatments on main stem diameter and height.

\begin{tabular}{|c|c|c|c|c|}
\hline \multirow{3}{*}{$\begin{array}{l}\text { Experimental } \\
\text { treatment }\end{array}$} & \multicolumn{4}{|c|}{ Cutting cycle } \\
\hline & \multicolumn{2}{|c|}{1 year $(\mathrm{R} 2 \mathrm{~S} 1)$} & \multicolumn{2}{|c|}{2 years $(\mathrm{R} 2 \mathrm{~S} 2)$} \\
\hline & $\begin{array}{c}\text { diameter } \\
\left(D_{1}\right) \\
(\mathrm{mm})\end{array}$ & $\begin{array}{l}\text { height } \\
(\mathrm{m})\end{array}$ & $\begin{array}{c}\text { diameter } \\
\left(D_{1}\right) \\
(\mathrm{mm})\end{array}$ & $\begin{array}{l}\text { height } \\
(\mathrm{m})\end{array}$ \\
\hline MONVISO & $21 \mathrm{~b}$ & $3.42 \mathrm{a}$ & $38 \mathrm{ab}$ & $4.70 \mathrm{a}$ \\
\hline AF2 & $21 \mathrm{~b}$ & $3.37 \mathrm{a}$ & 39 a & $4.65 \mathrm{ab}$ \\
\hline AF6 & $20 \mathrm{~b}$ & $3.09 \mathrm{~b}$ & $34 \mathrm{c}$ & $4.42 \mathrm{bc}$ \\
\hline SIRIO & $23 \mathrm{a}$ & $3.34 \mathrm{a}$ & $36 \mathrm{bc}$ & $4.36 \mathrm{c}$ \\
\hline High density & 20 & 3.30 & $34 \mathrm{~b}$ & 4.43 \\
\hline Low density & 22 & 3.31 & $40 \mathrm{a}$ & 4.63 \\
\hline Average & $21^{\mathrm{i}}$ & $3.30^{\mathrm{e}}$ & $37^{i}$ & $4.53^{\mathrm{e}}$ \\
\hline clones & $* *$ & $* *$ & $*$ & $* *$ \\
\hline density & n.s. & n.s. & $* *$ & n.s. \\
\hline
\end{tabular}

Means in vertical sequence not followed by the same letter are significantly different at $P=0.05$ according to LSD test. N.s., not significant; * $P=0.05$; ** $P=0.01$.

i, e: values with the same apex are significantly different at $\mathrm{P}=$ 0.05. R2S1: plants aged two years in root and one year in shoot; R2S2: plants aged two years both in root and shoot.

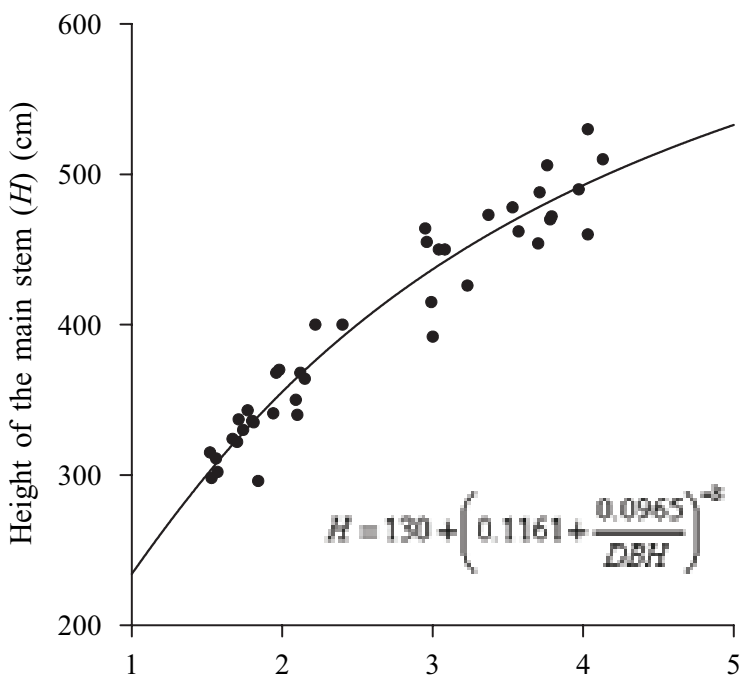

Diameter at breast height $(D B H)(\mathrm{cm})$

Figure 2. Relationship between $D B H(\mathrm{~cm})$ and $H$ for the main stem of poplar. The symbols are the determined values; the line is the fitted response according to model 1.

higher (4.65 odt ha-1) than that obtained from low planting density (3.59 odt $\mathrm{ha}^{-1}$ ); however, due to the low yield differences, an economical evaluation seems to be necessary in order to define the economical suitability for the two planting systems.

The yield obtained, in 2007, from R2S1 plants (one-year cutting cycle) showed not sig-
Table 4. Main effect of experimental treatments on yield (odt ha-1).

\begin{tabular}{|c|c|c|c|c|}
\hline \multirow{3}{*}{$\begin{array}{l}\text { Experimental } \\
\text { treatment }\end{array}$} & \multicolumn{4}{|c|}{ Cutting cycle } \\
\hline & \multicolumn{3}{|c|}{1 year } & \multirow{2}{*}{$\begin{array}{r}2 \text { years } \\
\text { R2S2 }\end{array}$} \\
\hline & R1S1 & R2S1 & $\mathrm{R} 1 \mathrm{~S} 1+\mathrm{R} 2 \mathrm{~S} 1$ & \\
\hline MONVISO & $4.61 \mathrm{a}$ & 5.77 & $10.39 \mathrm{a}$ & 12.86 \\
\hline AF2 & $4.28 \mathrm{ab}$ & 5.51 & $9.79 \mathrm{ab}$ & 12.07 \\
\hline AF6 & $3.87 \mathrm{~b}$ & 4.66 & $8.54 \mathrm{~b}$ & 10.98 \\
\hline SIRIO & $3.71 \mathrm{~b}$ & 5.16 & $8.88 \mathrm{~b}$ & 10.49 \\
\hline High density & $4.65 \mathrm{a}$ & 5.87 & $10.52 \mathrm{a}$ & 13.29 \\
\hline Low density & $3.59 \mathrm{~b}$ & 4.69 & $8.28 \mathrm{~b}$ & 9.91 \\
\hline Average & $4.12^{\mathrm{e}}$ & $5.28^{\mathrm{e}}$ & $9.40^{\mathrm{i}}$ & $11.60^{\mathrm{i}}$ \\
\hline clones & $*$ & n.s. & $*$ & n.s. \\
\hline density & $*$ & n.s. & * & n.s. \\
\hline clones vs density & n.s. & n.s. & n.s. & n.s. \\
\hline
\end{tabular}

Means in vertical sequence not followed by the same letter are significantly different at $P=0.05$ according to LSD test. N.s., not significant; *P=0.05; ** $P=0.01$.

$\mathrm{i}, \mathrm{e}$ : values with the same apex are significantly different at $\mathrm{P}=$ 0.05 . R1S1: plants aged one year both in root and shoot; R2S1: plants aged two years in root and one year in shoot; R2S2: plants aged two years both in root and shoot.

nificant differences between clones and planting densities, but significant differences were found between 2006 and 2007, with the average value (5.28 odt ha $\mathrm{ha}^{-1}$ ) significantly higher than that obtained in 2006 from R1S1 plants $(4.12$ odt ha ${ }^{-1}$ ) (Tab. 4). This is due both to the different length of the growing seasons and to the roots more developed in R2S1 plants than in R1S1 plants, that have allowed the highest shoots yield values. These results showed as the

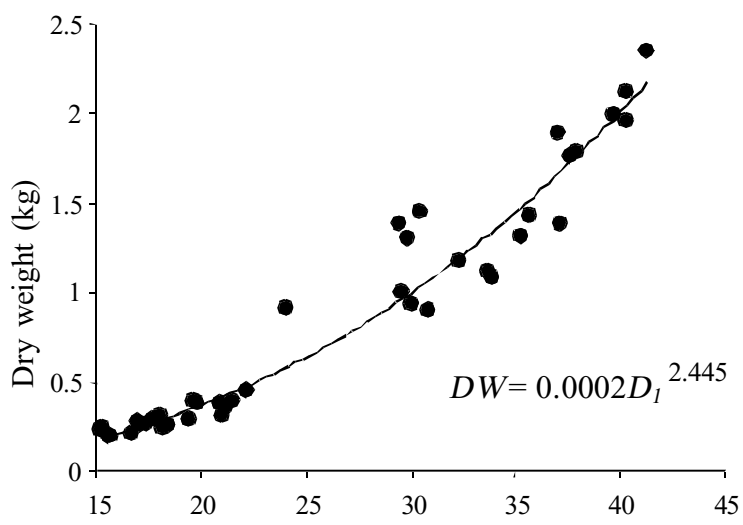

Diameter $D_{1}(\mathrm{~mm})$

Figure 3. Relationship between $D_{1}(\mathrm{~mm})$ and dry weight (kg) per plant for the poplar. The symbols are the determined values; the line is the fitted response according to model 2. 


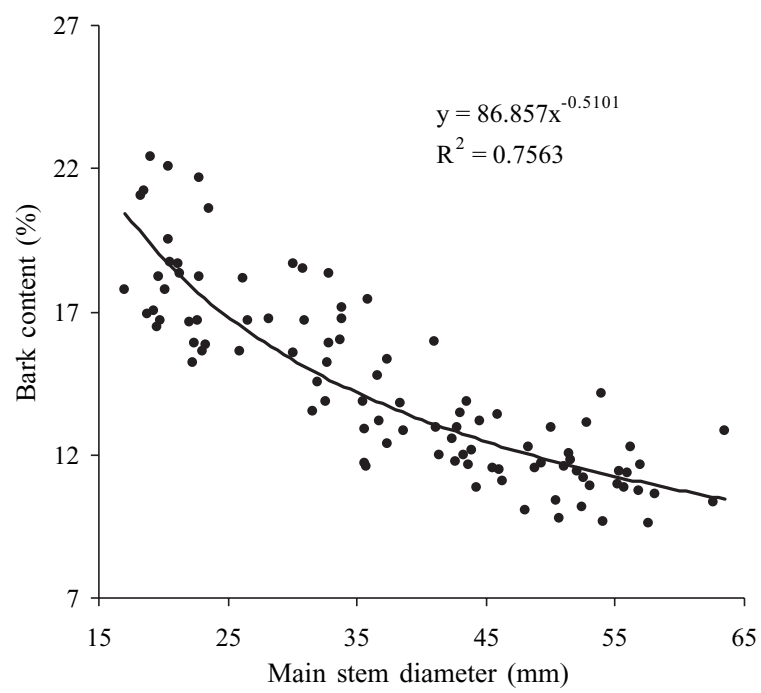

Figure 4. Relationship between main stem diameter at cutting height (50 $\mathrm{mm}$ above the ground) and percentage of bark surface on total cutting surface. The symbols are the determined values; the line is the fitted response according to equation 3 .

biomass production increase after the first year from planting and although this experiment is not able to define the age of plant to obtain the maximum biomass production, other authors have found that the highest biomass production can be obtained from R3S1 (plants aged three years in root and one year in shoot) or R4S2 (plants aged four years in root and two year in shoot) (Piccioni and Bonari, 2006).

Considering the yield obtained from R2S2 plants (two year cutting cycle), not significant differences were found between clones and planting densities (Tab. 4). However, the comparison between the two cutting cycles showed that the yield obtained from two-year cutting cycles (R2S2) (11.60 odt ha-1) was significantly higher than that obtained combining the two one-year cutting cycle (R1S1 + R2S1) (9.40 odt ha $^{-1}$ ) (Tab. 4). Monviso and AF2 averaged the highest dry weight values both in R1S1 + R2S1 and in R2S2 cutting cycles (Tab. 4).

In all years the moisture of biomass at the harvesting time showed not significant differences between clones and planting densities with an average value of $54 \%$.

The average yield biomass data obtained in these experimental trials are in agreement with those obtained in other experiments in Italy and Europe (Armstrong et al., 1999; Benetka et al., 2002; Verani and Sperandio, 2006). However, the yield data given in the literature for poplars in SRF differ considerably; this is because the results are strongly influenced by different types of experimental trials and site specific conditions (Kauter et al., 2003: Mareschi et al., 2005). As a consequence, the results are not transferable to different areas and so the agronomic experimental trials seem to be necessary to obtain the preliminary information on the performance of poplar SRF in each specific site of cultivation.

HHV and LHV obtained from R1S1 plant samples showed not significant differences between clones and densities, with the average values of $19.7 \pm 0.32 \mathrm{MJ} \mathrm{Kg}^{-1}$ and $19.4 \pm 0.32 \mathrm{MJ}$ $\mathrm{Kg}^{-1}$, respectively (Tab. 5). Similar results were obtained by Cuiping et al. (2004). On the basis

Table 5. High and low heat values (HHV, LHV) ( $\mathrm{MJ} \mathrm{kg}^{-1}$ of dry matter) and ash content (\% of dry matter) of poplar biomass. Standard errors are in parentheses.

\begin{tabular}{|c|c|c|c|c|c|}
\hline \multirow{4}{*}{$\begin{array}{l}\text { Experimental } \\
\text { treatment }\end{array}$} & \multicolumn{5}{|c|}{ Cutting cycle } \\
\hline & \multicolumn{4}{|c|}{1 year } & \multirow{3}{*}{$\begin{array}{c}2 \text { years } \\
\text { R2S2 } \\
\text { Ash }\end{array}$} \\
\hline & \multicolumn{3}{|c|}{ R1S1 } & $\mathrm{R} 2 \mathrm{~S} 1$ & \\
\hline & HHV & LHV & Ash & Ash & \\
\hline MONVISO & $20.4(1.10)$ & $20.1(0.48)$ & $4.2(0.41)$ & $4.3(0.55)$ & $4.1(0.17)$ \\
\hline AF2 & $19.9(0.45)$ & $19.7(0.07)$ & $3.2(0.13)$ & $3.3(1.11)$ & $3.1(0.05)$ \\
\hline AF6 & $19.2(0.09)$ & 18.9 (1.07) & $3.4(0.23)$ & $4.1(0.58)$ & $3.8(0.35)$ \\
\hline SIRIO & $19.1(0.60)$ & $18.8(0.61)$ & $3.4(0.67)$ & $3.5(0.25)$ & $3.4(0.36)$ \\
\hline High density & $19.7(0.63)$ & $19.4(0.64)$ & $3.7(0.38)$ & $4.5(0.25)$ & $3.8(0.25)$ \\
\hline Low density & $19.6(0.29)$ & $19.4(0.28)$ & $3.4(0.23)$ & $3.2(0.34)$ & $3.3(0.20)$ \\
\hline Average & $19.7(0.32)$ & $19.4(0.32)$ & $3.5(0.22)$ & $3.8(0.31)$ & $3.6(0.17)$ \\
\hline
\end{tabular}

R1S1: plants aged one year both in root and shoot; R2S1: plants aged two years in root and one year in shoot; R2S2: plants aged two years both in root and shoot. 
of heating values, $1 \mathrm{t}$ of poplar dry biomass contains the same energy of $0.46 \mathrm{t}$ of petroleum. Therefore the poplar biomass obtained from the first one-year cutting cycle R1S1 (4.12 odt ha-1) contains the same thermic energy of $1.9 \mathrm{t}$ of petroleum or $2060 \mathrm{~L}$ of diesel oil or $2209 \mathrm{~m}^{3}$ of natural gas.

Considering ash content, the results showed very similar data among treatments, with average values ranged from $3.5 \%$ to $3.8 \%$ (Tab. 5). However, the ash content found from high density biomass samples were higher than that obtained from low density samples (Tab. 5). This can be explain considering that bark has higher ash content than wood and the bark proportion, in the total biomass, decrease when the stem diameters increase, such as occur in low density planting systems and long cutting cycles with respect to high density planting systems and short cutting cycles (Senelwa and Sims, 1999; Tharakan et al., 2003; Werkelin et al., 2005). Concerning this, the equation relating main stem diameter (independent variable $\mathrm{x}$ ) to bark content (dependent variable y) was found:

$$
y=86.857 x^{-0.5101},\left(\mathrm{R}^{2}=0.756\right)
$$

The relationship showed as bark content dropped from $20 \%$ to $10 \%$ of the total cutting area when the stem diameter at the cutting height increased from $18 \mathrm{~mm}$ to $65 \mathrm{~mm}$, respectively (Fig. 4).

\section{Conclusions}

All poplar clones showed a very high stool survival with values ranged from $95 \%$ to $99 \%$. This characteristic is crucial in order to obtain a short establishment period and the optimal plant density during the next growing seasons. Among clones, Monviso and AF2 can be advisable thanks to the higher biomass production than AF6 and Sirio.

Considering planting density, low density (5500 plants ha ${ }^{-1}$ ) seems to be more advisable than high density (11000 plants ha- $\left.{ }^{-1}\right)$ in order to obtain good biomass production with low planting cost.

Considering cutting cycles, two-year cutting cycle allows higher biomass production (5.8 odt $\mathrm{ha}^{-1}$ year $^{-1}$ ) than one-year cutting cycle $(4.7 \mathrm{odt}$ ha $^{-1}$ year $^{-1}$ ), regardless of clones or density.
Concerning main stem height and diameter some interesting equation were found in order to explain the relationship between them or with biomass production. In particular, a functional relationship between dry biomass production and stool diameter, appropriate for this climatic area and environmental conditions, was found.

Analysis concerning wood energy content showed a good quality of poplar biomass thanks to high HHV and LHV values (an average of 19.7 $\mathrm{MJ} \mathrm{Kg}^{-1}$ and 19.4 $\mathrm{MJ} \mathrm{Kg}^{-1}$ ), low ash content (an average of $3.6 \%$ ) and low biomass humidity at harvest (an average of 54\%).

\section{Acknowledgements}

This study was supported by EU Project Co.Al.Ta.2 and Fondazione Cassa di Risparmio di Perugia.

\section{References}

Armstrong A., Johns C., Tubby I. 1999. Effects of spacing and cutting cycle on the yield of poplar grown as an energy crop. Biomass and Bioenergy, 17:305-314.

Bates D.M., Watts D.G. 1988. Nonlinear Regression Analysis and its Applications. John Wiley, New York, USA.

Benetka V., Bartáková I., Mottl J. 2002. Productivity of Populus nigra L. spp. nigra under short-rotation culture in marginal areas. Biomass and Bioenergy, 23:327-336

Cuiping L., Chuangzhia W., Yanyongjieb, Haitaoa H. 2004. Chemical elemental characteristics of biomass fuels in China. Biomass and Bioenergy, 27:119-130.

Di Muzio Pasta V., Negri M., Facciotto G., Bergante S., Maggiore T.M. 2007. Growth dynamics and biomass production of 12 poplar and 2 willow clones in a short rotation coppice in northern italy. Proceedings of 15 th Eur. Biomass Conference \& Exibition, 7-11 May, Berlin, 749-755.

Facciotto G. 1998. Le lavorazioni del suolo in pioppicoltura. Sherwood, 31:39-44.

Facciotto G., Zenone T., Sperandio G. 2003. Dalle colture da biomassa reddito incerto senza aiuti. Inf. Agr., 10:91-93.

Facciotto G., Bergante S., Lioia C., Rosso L., Mughini G., Zenone T., Nervo G. 2006. Produttività di pioppo e salice in piantagioni a turno breve. Forest@, 3,2:238252. Available online: http://www.sisef.it.

Hansen E.A. 1981. Root length in young hybrid Populus plantations: its implications for border width of research plots. For. Sci., 27:808-814.

Istituto Sperimentale per la Pioppicoltura. 2000. Pioppi- 
coltura: produzioni di qualità nel rispetto dell'ambiente. Diffusioni Grafiche s.p.a., Villanova Monferrato $(\mathrm{Al}), 76$.

Kauter D., Lewandowski I., Claupein W. 2003. Quantity and quality of harvestable biomass from Populus short rotation coppice for solid fuel use - a review of the physiological basis and management influences. Biomass and Bioenergy, 24:411-427.

Mareschi L., Paris P., Sabatti M., Nardin F., Giovanardi R., Manazzone S., Scarascia Mugnozza G. 2005. Le nuove varietà di pioppo da biomassa garantiscono produttività interessanti. Inf. Agr., 18:49-53.

Onofri A. 2006. Enhancing Excel capability to perform statistical analyses in agriculture applied research. In: Computational statistics and data analysis - Statistical Software Newsletters, Ed. by International Association for statistical Computing, 15/02/2006; www.csdassn.org/softlist.cfm.

Pellis A., Laureysens I., Ceulemans R. 2004. Growth and production of a short rotation coppice culture of poplar I. Clonal differences in leaf characteristics in relation to biomass production. Biomass and Bioenergy, 27:9-19.

Pettersson H. 1955. Die Massenproduktion des Nadelwaldes. Mitt. Forstl. Forsch. Anst. Schweden., 45:392580.

Piccioni E., Bonari E. 2006. SRF di pioppo nella pianura litoranea toscana. Sherwood, 128:31-36.
Pontailler J.Y., Ceulemans R., Guittet J. 1999. Biomass yield of poplar after five 2-year coppice rotations. Forestry, 72:157-163.

Senelwa K., Sims Ralph E.H. 1999. Fuel characteristics of short rotation forest biomass. Biomass and Bioenergy, 17:127-140.

Tharakan P.J., Volk T.A., Abrahamson L.P., White E.H. 2003. Energy feedstock characteristics of willow and hybrid poplar clones at harvest age. Biomass and Bioenergy, 25:571-580

Verani S., Sperandio G. 2006. Piantagioni energetiche su piccola scala. Sherwood, 128:37-41.

Werkelin J., Johan Skrifvars B., Hupa M. 2005. Ashforming elements in four Scandinavian wood species. Biomass and Bioenergy, 29:451-466.

Wirtschaftsuniversität Wien, 2009. The R Project for Statistical Computing. Department of Statistics and Mathematics, WU Wirtschaftsuniversität Wien. Available from: http://www.r-project.org/ (accessed $10 \mathrm{Ju}-$ ly 2009).

Zalesny J.A., Zalesny Jr. R.S., Coyle D.R., Hall R.B. 2007. Growth and biomass of Populus irrigated with landfill leachate. Forest Ecology and Management, 248:143-152.

Zavitkovski J. 1981. Small plots with unplanted plot border can distort data in biomass production studies. Can. J. For. Res., 11:9-12. 